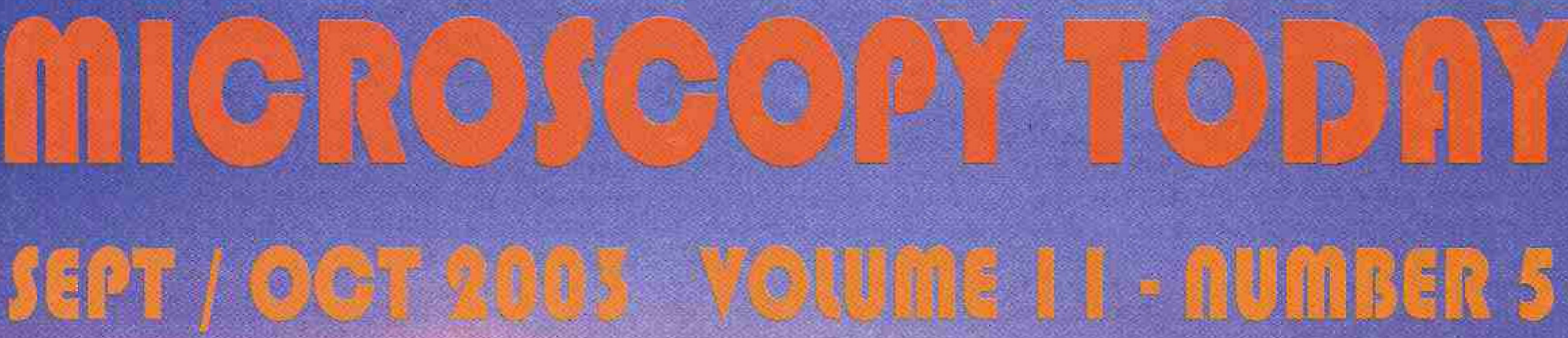

से मी
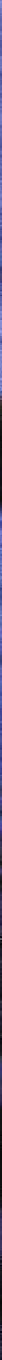


\section{Print Your Own Organs!}

Stephen W. Carmichael, ${ }^{1}$ Mayo Clinic carmichael.stephen@mayo.edu

Would you believe it might be possible to build organs using an ink-jet printer? In a remarkable pair of articles, Thomas Boland and his collaborators describe a modified printer that promises to be able to do exactly that. ${ }^{2}$

The first article of this pair describes the software and hardware to arrange cells in two dimensions, just as a printer arranges droplets of ink on a flat piece of paper. The software that normally controls the position of a drop of ink is modified to position a drop containing one or two cells in suspension onto a substrate. Unlike a color printer, which positions primary colors near each other to create the selected color, it is often desirable to superimpose cells directly on top of each other, and the software can be modified to do this. A major concern is keeping the cells hydrated, since the volume of a drop is small and evaporation is rapid. However, the cells seemed to survive this precise placement process.

Whereas, the first paper described placement of cells in two dimensions, the second paper dealt with the technical challenges of placing cells accurately in a three dimensional matrix. This was primarily accomplished by depositing cells in a gel of finite thickness; either a collagen gel or a "thermo-reversible" gel. Nontoxic, biodegradable, thermo-reversible gels that are fluid at room temperature and solidify as they approach body temperature could be used as the "paper" and cells as the "ink." Thereby twodimensional constructs are stacked upon one another to create a three-dimensional structure with cells, or aggregates of cells, with a specific spatial relationship to each other, i.e., an organ. Furthermore, additional extracellular matrix may be formed by the cells, thus providing more "glue" for cell aggregate fusion and serving as a type of tethering device for promoting the self-assembly of printed tissue constructs.
Boland et al. rightly point out that transplantation as a routine medical care is being limited by a shortage of donor organs. They discuss at length a variety of possible solutions, including artificial mechanical organs, xenotransplantation (non-human organs), classical tissue engineering, and rapid prototyping technology. Each has some promise and many pitfalls. The technique of "organ printing" offers some advantages by using cells from the patient and a technology that can be implemented on a time frame of minutes.

Proof of concept is offered in these two articles. Functional cells could be harvested from the patient and grown up in culture into sufficient numbers. Various cells, or aggregates of cells, could be arranged in a specific pattern that would constitute the parenchyma of the "printed" organ. This would be done, layer by layer, on appropriate gels that would constitute the stroma of the new organ. Blood vessels could be incorporated within the three dimensional structure. It may then be possible to remove the diseased organ from the patient, substituting the newly "printed" organ.

It is clear that this technology is far from maturity, but the initial results appear to be promising. Boland et al. have assessed the feasibility of this relatively simple technology and have attempted to remove some of the most obvious technological barriers to its use. It would be a spectacular advancement in transplantation biology if new organs could be "printed" and the shortage of donor organs relieved!

\section{References:}

1. The author gratefully acknowledges Dr. Thomas Boland for reviewing this article.

2. Wilson, C.W., Jr., and T. Boland, Cell and organ printing 1: Protein and cell printers, Anat. Rec. 272A:491-496, 2003; Boland, T., V. Mironov, A. Gutowska, E.A. Roth, and R.R. Markwald, Cell and organ printing 2: Fusion of cell aggregates in three-dimensional gels, Anat. Rec. 272A: $497-502,2003$

\section{InDex or ARHIOLS}

Print Your Own Organs!

Stephen W. Carmichael, ${ }^{1}$ Mayo Clinic

Atom Probes LEAP Ahead.

Thomas F. Kelly and Amy A. Gribb, Imago Scientific Inst. Corp.

Microscopy At The Ends Of The Earth. Dee Breger, Lamont-Doherty Earth Observatory, Columbia University

A Si Multi-Cathode Detector For Microanalysis Applications.........24

S. Barkan \& L. Feng, Radiant Detector Technologies, J. S. Iwanczyk, B. E. Patt \& C.

R. Tull, Photon Imaging, the., D. E. Newbury and J. A. Small, NIST

Techniques for Combinatorial and High-Throughput Microscopy

Part 1: Gradient Specimen Fabrication for Polymer Thin Film Research ....26 A. Sehgal, A. Karim, C. Stafford and M Fasolka, NIST

Microscopical Studies of World Trade Center Disaster Dust Particles.........32 J.R. Millette, R. Boltin, P. Few, and W. Tumer, Ji, MVA, inc.

Preparation Of Soil Samples For Light And Transmission Electron

Microsopy.

Gordon Vrdoljak, UC Berkeley

A New Look At Cast Iron Microstructure.

Janina M. Radzikowska, Foundry Research Institute, Krakow, Poland

Precision and Detection Limits for EDS Analysis in the SEM.

Eric Lifshin, University at Albany, Albany, NY \& Raynaid Gauvin, McGill University, Montreal, Quebec

Adding Color To Grayscale Images .50 Jerry Sedgewick, University of Minnesota

New and Interesting at M\&M-2003 .51
3 Industry News .52

Support Films with Uniform Hole Size ...............................................54

Kenneth H. Downing, Lawrence Berkeley National Laboratory

Cleaning a Cold Cathode Gauge Tube . .54 Owen P. Mills, Michigan Technological University

Zigzag Edges in SEM Micrographs. .55 A. F. Yang and M. Kaláb, Agriculture and Agri-Food Canada* Ottawa, Ontario, Canada

NetNotes.

Microscopy CD-ROMs For Children: A Bibliography. .58 Caroline Schooley, Project MICRO Coordinator, MSA

Index of Advertisers 62

\section{ABOUT THE GOVER}

\section{Microscopy At The Ends Of The Earth Dee Breger}

Many microscopy samples are collected on expeditions that range across the globe, including from an international fleet of research vessels like the one on this month's cover. The view shows the midwinter sun just peeking above the northern horizon, as seen from the U.S. icebreaker R/V Nathaniel B. Palmer while she was crunching through heavy pack ice for an Antarctic rendezvous with the Russian station Mirnyy in 1996. Photo (C) Dee Breger 